\title{
KEPUASAN PELANGGAN BERDASARKAN DIMENSI TIMELINESS KUALITAS JASA EVANS DAN LINDSAY DENGAN METODE IMPORTANCE PERFORMANCE ANALYSIS
}

\author{
Customer Satisfaction Based on Timeliness Service Quality Dimension of Evans and Lindsay \\ with Importance Performance Analysis
}

Puput Hermanti

Ikatan Bidan Indonesia (IBI) Sidoarjo

E-mail: puput.hermanti-14@fkm.unair.ac.id

\begin{abstract}
Based on Keputusan Menteri Pendayagunaan Aparatur Negara Nomor KEP/25/M.PAN/2004 level of customer satisfaction of a service can be judged by the Community Satisfaction Index, there are fourteen elements of these services have a standard that is equal to $85 \%$. General clinic and specialist in Menur Mental Hospital Surabaya has a Community Satisfaction Index by $75.11 \%$ which is below the standard of $85 \%$. This research was purposed to analyzing customer satisfaction based on the level of importance of hospital performance in timeliness dimension of Evans and Lindsay service quality with importance performance analysis method. The research design was observational with cross sectional approach. Research conducted on November 2016 included 98 customer in General clinic and Specialist in Menur Mental Hospital Surabaya as respondents. Data were analyzed by Importance Performance Analysis. The result showed respondents considered that all aspects of the timeliness dimension is very important, especially for check the wait time $\leq 60$ minutes aspect with mean importance value is 3.58, and performance service respondents considered check wait time $\leq 60$ minutes aspect had smaller mean value performance (2.44) from the mean performance timeliness (2.84). The conclusion is customer not satisfied with timeliness dimension of Evans and Lindsay service quality.
\end{abstract}

Keywords: Customer Satisfaction, Importance-Performance Analysis, Timeliness

\section{PENDAHULUAN}

Pengelolaan kualitas jasa rumah sakit harus berfikir tentang pelayanan yang terbaik yang harus diberikan kepada pelanggan (pasien dan keluarga) saat mereka baru masuk ke lingkungan rumah sakit. Kepuasan pelanggan merupakan salah satu profit center dari rumah sakit yang dipengaruhi oleh performance rawat jalan. Tingkat kepuasan dapat berasal dari terpenuhinya harapan yang direfleksikan oleh tingkat kepentingan dan penilaian/ kinerja oleh pelanggan terhadap jasa pelayanan rumah sakit. Rasa tenang dan yakin bahwa mereka berada di rumah sakit yang tepat. Pada saat itulah dimana kebutuhan pelanggan telah terpenuhi maka akan timbul rasa puas dan kecenderungan pelanggan untuk setia atau loyal dalam memanfaatkan pelayanan jasa apabila dibutuhkan (Azwar, 2008).
Menurut Penilaian Kinerja KEPMENPAN

tingkat kepuasan pelanggan terhadap jasa suatu pelayanan dapat dinilai berdasarkan Indeks Kepuasan Masyarakat, terdapat empat belas unsur pelayananan yang telah terstandar yaitu sebesar $85 \%$.

Salah satu metode untuk mengukur tingkat kepuasan pelanggan adalah menggunakan Importance Performance Analysis dengan menggunakan dimensi kualitas jasa menurut evans dan Lindsay yang terdiri dari delapan dimensi yaitu meliputi waktu (time), ketepatan waktu (timeliness), kelengkapan (completeness), keramahan dan kesopanan (courtesy), ketaat-azasan (consistency), keterjangkauan dan kenyamanan (accessibility and convenience), ketelitian (accuracy) dan kecepattanggapan (responsiveness) (Magal dan Levenburg 2005; Evans, W dan Lindsay, 2007). Namun, pada penelitian ini hanya dibatasi pada dimensi 
ketepatan waktu (timeliness). Penelitian ini bertujuan untuk mengukur kepuasan pelanggan dengan dimensi ketepatan timeliness) waktu (karena dari keempat belas unsur Indeks Kepuasan Masyarakat yang ada kecepatan pelayanan yang ada di Rumah Sakit Jiwa Menur memiliki nilai yang paling rendah yaitu sebesar $77,53 \%$.

\section{PUSTAKA}

\section{Dimensi Kualitas Jasa}

Menurut Evans dan Lindsay (2007) terdapat delapan dimensi kualitas jasa, yang terdiri dari waktu (Time) dimensi waktu yang dimaksud adalah waktu tiba pegawai datang ke tempat pelayanan, serta yang terkait dengan waktu operasional pelayanan

Ketepatan Waktu (Timeliness) terkait dengan durasi pelayanan yang disesuaikan dengan Standar Pelayanan Minimal yang ada, kelengkapan (Completeness) dari segi peralatan, fasilitas dan obat-obatan menjadi suatu pertimbangan pelanggan dalam menggunakan jasa pelayanan kesehatan, semakin lengkap unsur tersebut maka akan meningkatkan kepuasan pelanggan. Keramahan dan kesopanan (Courtesy) dimensi ini sangat penting karena pelayanan kesehatan mengedepankan interaksi dengan pelanggan, keramahan dan kesopanan petugas yang terlibat pada suatu fasilitas kesehatan. Ketaat-azasan (Consistency) terkait dengan keandalan pemberi pelayanan dalam memberikan pelayanan kepada pelanggan. Keterjangkauan dan kenyamanan (Accessibility And Convenience) dari segi tarif maupun akses serta kenyamanan dalam menjalankan pelayanan kesehatan. Ketelitian (Accuracy) harapan pelanggan terhadap ketelitian tenaga kesehatan dalam memberi pelayanan kesehatan akan menjauhkan pasien terhadap rasa ketidakpercayaan dalam memilih pelayanan kesehatan. Kecepat-Tanggapan (Responsiveness) merupakan salah satu dimensi yang harus diperhatikan karena berdampak pada kepuasan pelanggan.

\section{Importance Performance Analysis}

Importance Performance Analysis mempunyai tujuan untuk mengukur hubungan antara persepsi pelanggan dan prioritas peningkatan kualitas produk/jasa yang dikenal pula sebagai quadrant analysis (Brandt, 2000)

\section{Metode Importance Performance Analysis} meminta pelanggan untuk menilai tingkat kepentingan dari harapan terhadap pelayanan yang diberikan dan penilaian tingkat kinerja dari pelayanan yang telah diberikan penyedia layanan kemudian nilai rata- rata dari tingkat kepentingan dan tingkat kinerja akan dianalisis di Importanceperformance map. Map ini menunjukkan bidang atau aspek-aspek apa yang perlu dipertahankan dan aspek apa yang perlu dikurangi prioritasnya. Kinerja pada level cut off point sumbu horizontal atau diatasnya mencerminkan proporsi pelanggan yang sangat puas (delighted) (Tijptono dan Chandra, 2007).

Importance performance map. terbagi menjadi empat bagian yaitu kuadran I, Kuadran II, kuadran III dan Kuadran IV 


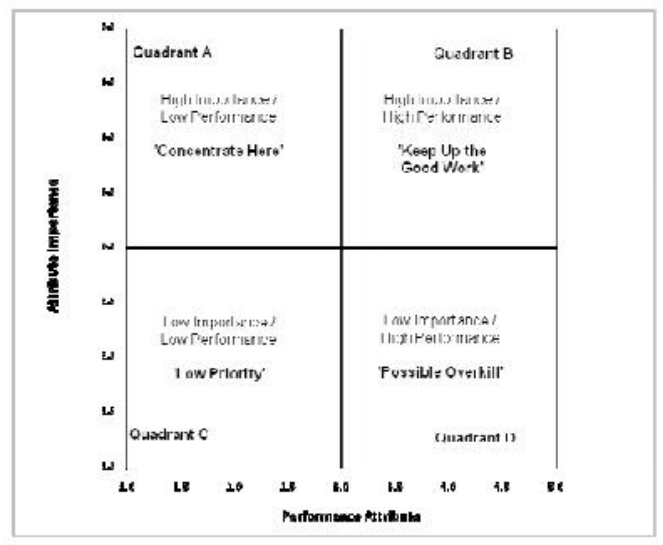

Gambar 1. Importance Performance Map (Sumber: Hock and Sarstedt, 2010)

Pada gambar 1 dapat dijelaskan bahwa Kuadran A/ I (Concentrate Here) menunjukkan bahwa jenis pelayanan yang terdapat dalam kuadran ini merupakan suatu tantangan yang memerlukan tindakan korektif dengan segera dan harus menjadi prioritas utama, jenis pelayanan ini sangat penting namun organisasi tidak memberikan kinerja yang baik sehingga pelanggan tidak puas, organisasi harus konsentrasi penuh pada pelayanan tersebut.

Kuadran B/ Kuadran II (Keep Up The Good Work) berisi jenis pelayanan yang kuat, jenis pelayanan yang penting dan diberikan dengan baik oleh organisasi sehingga pelanggan merasa puas, hasil kerja ini harus dipertahankan oleh organisasi agar pelanggan yang merasa puas menjadi loyal terhadap organisasi.

Kuadran C/ Kuadran III ( Low Priority) menunjukkan jenis pelayanan yang tidak penting yang diberikan dengan kinerja rendah dan tidak mendapat perhatian dari pelanggan, jenis pelayanan ini memiliki prioritas rendah. Peningkatan atribut-atribut dalam kuadran ini dapat dipertimbangkan kembali karena pengaruhnya terhadap manfaat yang dirasakan oleh pelanggan sangat kecil.

Kuadran D/ Kuadran IV (Possible Overkill), menunjukkan jenis-jenis pelayanan yang tidak penting namun diberikan dengan kinerja yang baik dan sumber daya yang berada pada pelayanan ini dapat dialihkan ke jenis pelayanan yang lain atau mengkomunikasikan kepada pelanggan bahwa pelayanan tersebut perlu diberikan. Penilaian jenis pelayanan didasarkan pada pandangan pelanggan atas tingkat kepentingan (yang direfleksikan oleh harapan) dan kinerja yang ditunjukkan organisasi atau pemberi pelayanan.

Pada metode Importance Performance Analysis dapat diketahui gap atau kesenjangan antara tingkat kepentingan yang direfleksikan oleh harapan dan penilaian kinerja. Apabila gap positif maka pelanggan puas dan sebaliknya. Semakin kecil gap maka semakin baik penilaian pelayanannya. Nilai gap diperoleh dari Gap= (Mean (X) - Mean (Y)) akan digunakan untuk menentukan tingkat kepuasan pelanggan dengan rumus yang dikembangkan oleh Parasuraman, Zeithaml dan Berry (1998) dalam Sihombing (2002) yaitu tingkat kepuasan adalah $\sum$ (bobotx gap rata-rata tiap dimensi. Masing-masing dimensi oleh pelanggan diberi bobot dalam bentuk persentase sehingga total bobot adalah $100 \%$. Bila pada penjumlahan diperoleh hasil >-1 dikatakan rata-rata kinerja baik dan responden umumnya puas dan sebaliknya apabila tingkat kepuasan $<-1$ kinerja masih kurang baik dan hal itu berarti pelanggan kurang puas (Sihombing,2002) 


\section{METODE}

Penelitian ini merupakan penelitian observasional dengan pendekatan cross sectional karena pengumpulan data variabel hanya dalam satu periode waktu tertentu. Populasi dari penelitian ini adalah seluruh pelanggan (pasien/ keluarga pasien/ pengantar) pada Poli Umum dan Spesialis Rumah Sakit Jiwa Menur Surabaya

Sampel diambil dengan teknik purposive Sampling dengan jumlah populasi sebesar 3918 dan sampel 98 orang (pelanggan yang telah berkunjung minimal sebanyak dua kali. Sebelum pengambilan sampel dilakukan wawancara terlebih dahulu kepada calon responden dan menanyakan jumlah kunjungan sebelumnya.

Data penelitian ini berupa data primer yang diperoleh dengan instrumen kuesioner, yang berisi tentang pernyataan terkait dengan tingkat kepentingan dan pernyataan yang terkait dengan penilaian kinerja dan selanjutnya data akan dianalisis menggunakan Importance Performance Analysis. Setelah didapatkan skor dari seluruh penyataan yang ada maka rata-rata tingkat kepentingan dan kinerja akan dimasukkan ke dalam Importance Performance Matrix, kemudian dilakukan analisis gap antara tingkat kepentingan dan penilaian kinerja, perhitungan nilai gap ini akan digunakan untuk menilai kepuasan pelanggan,
Apabila gap positif maka pelanggan puas dan sebaliknya. Semakin kecil gap maka semakin baik penilaian pelayanannya. Bila pada penjumlahan diperoleh hasil >-1 dikatakan rata-rata kinerja baik dan pelanggan umumnya puas begitu juga sebaliknya

\section{HASIL DAN PEMBAHASAN}

Karakteristik Responden

Berikut merupakan tabel karakteristik pelanggan Poli Umum dan Spesialis Rumah Sakit Jiwwa Menur Surabaya yang menjadi responden, berdasarkan Jenis Kelamin

Tabel 1. Jenis Kelamin Responden di Poli Umum dan Spesialis Rumah Sakit Jiwa Menur Surabaya

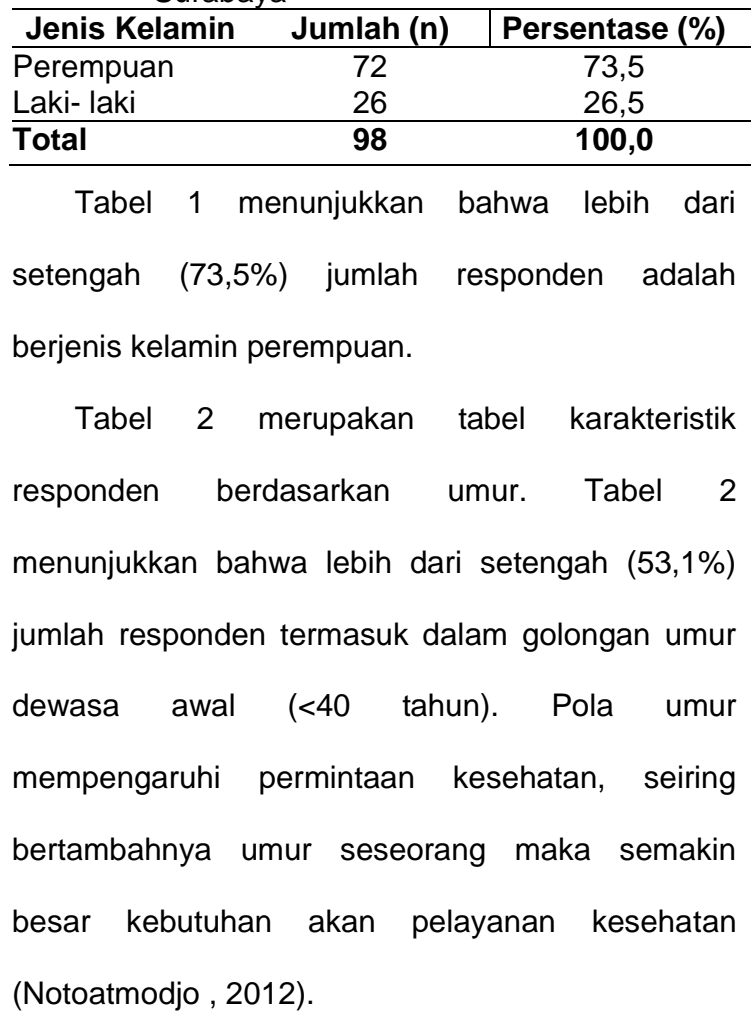

Tabel 2. Umur Responden di Poli Umum dan Spesialis Rumah Sakit Jiwa Menur Surabaya

\begin{tabular}{lcc}
\hline \multicolumn{1}{c}{ Golongan Umur } & Jumlah $(\mathbf{n})$ & Persentase (\%) \\
\hline Dewasa awal (<40 tahun) & 52 & 53,1 \\
Dewasa madya (40-60tahun) & 42 & 42,9 \\
Dewasa akhir (>60 tahun) & 4 & 4,0 \\
\hline Total & $\mathbf{9 8}$ & $\mathbf{1 0 0 , 0}$ \\
\hline
\end{tabular}


Tabel dibawah ini merupakan tabel karakteristik responden berdasarkan tingkat pendidikan:

Tabel 3. Tingkat Pendidikan Responden di Poli Umum dan Spesialis Rumah Sakit Jiwa Menur Surabaya

\begin{tabular}{lcc}
\hline \multicolumn{1}{c}{$\begin{array}{c}\text { Tingkat } \\
\text { Pendidikan }\end{array}$} & Jumlah (n) & Persentase (\%) \\
\hline Tidak pernah & 2 & 2,1 \\
sekolah & & \\
SD/sederajat & 17 & 17,3 \\
SMP/ sederajat & 31 & 31,6 \\
SMA/ sederajat & 32 & 32,7 \\
Diploma & 6 & 6,1 \\
S1/S2 & 10 & 10,2 \\
\hline Total & $\mathbf{9 8}$ & $\mathbf{1 0 0 , 0}$ \\
\hline
\end{tabular}

Tabel 3 menunjukkan bahwa kurang dari setengah $(32,7 \%)$ jumlah responden memiliki tingkat pendidikan SMA/sederajat. Hal ini berpengaruh terhadap kepuasan pasien, semakin tinggi tingkat pendidikan pelanggan maka tingkat kepuasannya semakin rendah. Hal ini cukup beralasan, karena pada umumnya seseorang yang memiliki tingkat pendidikan rendah tidak mempunyai harapan yang terlalu tinggi kepada orang lain atas dirinya. Mereka sudah cukup puas bila kebutuhan dasarnya terpenuhi. Sebaliknya, seseorang yang memiliki tingkat pendidikan tinggi mempunyai harapan yang tinggi terhadap orang lain atas dirinya (Anjaswarni , 2002).

Tabel dibawah ini merupakan tabel karakteristik responden berdasarkan jenis pekerjaan:
Tabel 4. Jenis Pekerjaan Responden di Poli Umum dan Spesialis Rumah Sakit Jiwa Menur Surabaya

\begin{tabular}{lcc}
\hline \multicolumn{1}{c}{$\begin{array}{c}\text { Jenis } \\
\text { Pekerjaan }\end{array}$} & Jumlah (n) & Persentase (\%) \\
\hline Ibu Rumah & 34 & 34,7 \\
Tangga & & \\
Karyawan & 24 & 24,5 \\
Swasta & & \\
Wirasawasta & 24 & 24,5 \\
PNS & 6 & 6,1 \\
Petani & 1 & 1,0 \\
Pensiunan & 1 & 1,0 \\
Lain-lain & 8 & 8,2 \\
\hline Total & 98 & 100,0 \\
\hline
\end{tabular}

Tabel 4 menunjukkan bahwa kurang dari setengah (34,7\%) jumlah responden adalah ibu rumah tangga.

Ekonomi adalah kegiatan menghasilkan uang di masyarakat untuk memenuhi kebutuhan hidup, sehingga responden yang sebagian besar adalah ibu rumah tangga yang tidak berpenghasilan akan mempengaruhi pemilihan fasilitas pelayanan kesehatan. Simamora (2004)

Tabel 5 merupakan karakteristik responden berdasarkan pendapatan keluarga perbulan, Tabel 5 menunjukkan bahwa lebih dari setengah $(57,1 \%)$ jumlah responden memiliki pendapatan keluarga perbulan Rp. $<1.000 .000$, artinya pendapatan keluarga responden dibawah Upah Minimimum Kabupaten/ Kota Surabaya yaitu Rp. 3.046.000.

Tabel 5. Pendapatan Keluarga Per Bulan Responden di Poli Umum dan Spesialis Rumah Sakit Jiwa Menur

\begin{tabular}{lcc}
\multicolumn{1}{c}{ Surabaya } & & \\
\hline \multicolumn{1}{c}{ Pendapatan perbulan } & Jumlah $(\mathbf{n})$ & Persentase (\%) \\
\hline$<1.000 .000$ & 56 & 57,1 \\
$1.000 .000-3.045 .000$ & 33 & 33,7 \\
$3.046 .000-5.000 .000$ & 7 & 7,1 \\
$>5.000 .000$ & 2 & 2,1 \\
\hline Total & $\mathbf{9 8}$ & $\mathbf{1 0 0 , 0}$
\end{tabular}


Rendahnya pendapatan keluarga dapat menyebabkan kemiskinan sehingga berpengaruh terhadap akses pendidikan dan kesehatan. Akses kesehatan yang rendah dapat disebabkan oleh ketidak mampuan daya beli pelayanan kesehatan akibat kemiskinan sehingga sulit dalam mencapai pelayanan kesehatan, sehingga secara tidak langsung mempengaruhi indeks kepuasan Masyarakat (IKM) terhadap suatu pelayanan kesehatan (Notoatmodjo, 2012).

\section{Tingkat Kepentingan}

Tingkat kepentingan responden terhadap pelayanan Poli Umum dan Spesialis Rumah Sakit Jiwa Menur Surabaya berdasarkan Dimensi Kualitas ketepatan waktu (timeliness) dapat dilihat pada tabel 6 .

Tabel 6 menunjukkan tingkat kepentingan responden terhadap pelayanan Poli Umum dan
Spesialis Rumah Sakit Jiwa Menur Surabaya berdasarkan dimensi ketepatan waktu (timeliness). Responden menilai sangat penting terhadap seluruh aspek pada dimensi ketepatan waktu (timeliness). Hal ini terbukti dengan penilaian masing-masing aspek oleh responden memiliki nilai mean yang mencapai 4, khususnya pada aspek prosedur administrasi (pendaftaran) $\leq 10$ menit $(3,36)$ dan waktu tunggu periksa $\leq 60$ menit $(3,58)$. Nilai mean dari aspek tersebut berada di atas nilai mean ketepatan waktu (timeliness) $(3,33)$.

\section{Penilaian Kinerja}

Penilaian responden terhadap kinerja pelayanan Poli Umum dan Spesialis Rumah Sakit Jiwa Menur Surabaya berdasarkan Dimensi kualitas ketepatan waktu (timeliness) dapat dilihat pada tabel 7.

Tabel 6.Tingkat Kepentingan Responden Terhadap Pelayanan Poli Umum dan Spesialis RS. Jiwa Menur Surabaya Berdasarkan Dimensi Kualitas ketepatan waktu (timeliness)

\begin{tabular}{|c|c|c|c|c|c|c|}
\hline \multirow{2}{*}{ Dimensi ketepatan waktu (timeliness) } & \multicolumn{4}{|c|}{ Tingkat Kepentingan } & \multirow[t]{2}{*}{ Jumlah (Y) } & \multirow{2}{*}{$\begin{array}{c}\text { Mean } \\
(\bar{Y})\end{array}$} \\
\hline & 1 & 2 & 3 & 4 & & \\
\hline $\begin{array}{l}\text { Prosedur administrasi (pendaftaran) } \leq \\
10 \text { menit }\end{array}$ & 3 & 8 & 37 & 50 & 330 & 3,36 \\
\hline Waktu tunggu periksa $\leq 60$ menit & & & 41 & 57 & 351 & 3,58 \\
\hline $\begin{array}{l}\text { Jam buka pelayanan rawat jalan pukul } \\
08.00-13.00 \text { setiap hari kerja }\end{array}$ & & 26 & 39 & 33 & 301 & 3,07 \\
\hline
\end{tabular}

Tabel 7. Penilaian Responden Terhadap Kinerja Pelayanan Poli Umum dan Spesialis Rumah Sakit Jiwa Menur Surabaya Berdasarkan Dimensi Kualitas ketepatan waktu (timeliness)

\begin{tabular}{lccccc}
\hline \multicolumn{1}{c}{$\begin{array}{c}\text { Dimensi ketepatan waktu } \\
\text { (timeliness) }\end{array}$} & $\mathbf{1}$ & $\mathbf{2}$ & $\mathbf{3}$ & $\mathbf{4}$ & $\begin{array}{c}\text { Jumlah (Y) } \\
\text { Mean } \\
(\overline{\mathbf{Y}})\end{array}$ \\
\hline $\begin{array}{l}\text { Prosedur administrasi (pendaftaran) } \\
10 \text { menit }\end{array}$ & 30 & 53 & 15 & 279 & 2,8 \\
Waktu tunggu periksa $\leq 60$ menit & 61 & 30 & 7 & 240 & 2,44 \\
Jam buka pelayanan rawat jalan pukul & & 68 & 30 & 324 & 3,30 \\
$\begin{array}{l}\text { Ji.00 - 13.00 setiap hari kerja } \\
\text { Jumlah } \\
\text { Mean performance timeliness }\end{array}$ & & & & $\mathbf{2 8 1}$ & $\mathbf{2 , 8 4}$ \\
\hline
\end{tabular}


Tabel 7 menunjukkan dari ketiga aspek yang terdapat dalam dimensi ketepatan waktu (timeliness), responden menilai bahwa aspek waktu tunggu periksa $\leq 60$ menit pada pelayanan Poli Umum dan Spesialis Rumah Sakit Jiwa Menur Surabaya mempunyai kinerja yang tidak baik, hal ini dapat diketahui dari mean penilaian responden terhadap aspek ini lebih kecil $(2,44)$ dari mean performance timeliness $(2,84)$.

\section{Importance Performance Map}

Jika tingkat kepentingan dan penilaian responden terhadap dimensi kualitas waktu (time) dipetakan ke dalam Importance Performance map maka akan diketahui letak kuadran masing-masing aspek dari dimensi waktu (time) adalah sebagai berikut:

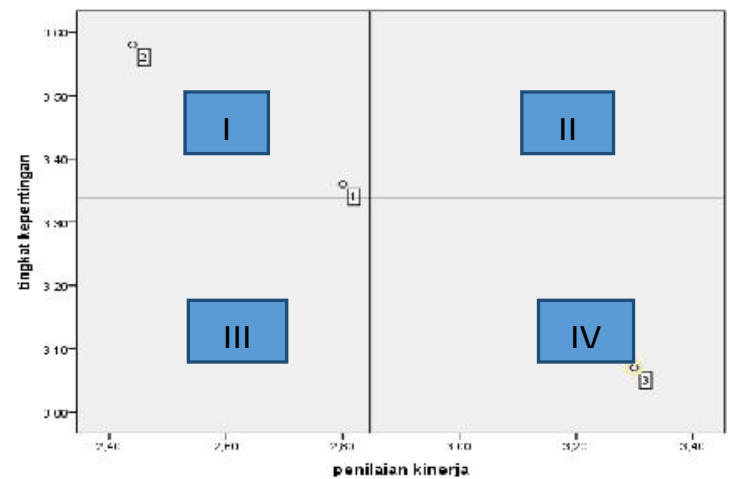

Gambar 2. Importance Performance Map Dimensi Ketepatan Waktu (timeliness)

Keterangan:

1. Prosedur administrasi (pendaftaran) $\leq 10$ menit $(3,36 ; 2,8)$

2. Waktu tunggu periksa $\leq 60$ menit $(3,58 ; 2,44)$

3. Jam buka pelayanan rawat jalan pukul $08.00-$ 13.00 setiap hari kerja $(3,07 ; 3,3)$

\section{Analisis Gap}

Berdasarkan hasil penelitian yang telah dilakukan maka didapatkan nilai mean tingkat kepentingan dan nilai mean penilaian masingmasing aspek dari responden terhadap kinerja pelayanan Poli Umum dan Spesialis Rumah Sakit Jiwa Menur Surabaya, dari nilai mean tersebut dilakukan analisis gap pada masing-masing dimensi yang dapat dilihat pada tabel 8 berikut ini:

Tabel 8. Gap antara Tingkat Kepentingan dan Penilaian Responden Terhadap Kinerja Pelayanan Poli Umum dan Spesialis Rumah Sakit Jiwa Menur Surabaya Berdasarkan Dimensi Ketepatan Waktu (Timeliness)

\begin{tabular}{|c|c|c|}
\hline $\begin{array}{c}\text { Dimensi } \\
\text { ketepatan waktu } \\
\text { (timeliness) }\end{array}$ & $\begin{array}{l}\text { Gap } \\
(\text { Mean } \\
(\mathrm{X})- \\
\text { Mean } \\
(\mathrm{Y}))\end{array}$ & Kepuasan \\
\hline $\begin{array}{l}\text { Prosedur } \\
\text { administrasi } \\
\text { (pendaftaran) } \leq 10 \\
\text { menit }\end{array}$ & $-0,56$ & Tidak Puas \\
\hline $\begin{array}{l}\text { Waktu tunggu } \\
\text { periksa } \leq 60 \\
\text { menit }\end{array}$ & $-1,14$ & Tidak Puas \\
\hline $\begin{array}{lr}\text { Jam } & \text { buka } \\
\text { pelayanan rawat } \\
\text { jalan pukul } 08.00 \\
-13.00 \text { setiap hari } \\
\text { kerja }\end{array}$ & 0,23 & Puas \\
\hline $\begin{array}{l}\text { Mean gap } \\
\text { timeliness }\end{array}$ & $-0,49$ & Tidak Puas \\
\hline
\end{tabular}

Tabel 8 menunjukkan dari ketiga aspek yang terdapat dalam dimensi ketepatan waktu (timeliness) aspek waktu tunggu periksa $\leq 60$ menit memiliki nilai mean gap yang paling besar $(-1,14)$.

\section{Prosedur administrasi (pendaftaran) $\leq 10$ menit}

Prosedur administrasi yang berjalan cepat dapat mempersingkat waktu pasien dan keluarga pasien sehingga bisa mendapatkan pelayanan yang dibutuhkan dengan segera. Prosedur administrasi (pendaftaran) yang lebih lama dibandingkan dari standar yang harus dipenuhi yaitu $\leq 10$ menit dapat disebabkan oleh beberapa faktor seperti kerjasama rumah sakit dengan BPJS menyebabkan bertambahnya jumlah kunjungan pada Poli Umum dan Spesialis Rumah Sakit. Jiwa Menur Surabaya namun hal itu tidak diikuti dengan penambahan 
jumlah tenaga perekam medis dan administrasi pada instalasi pelayanan tersebut. Aspek ini terdapat pada kuadran I menunjukkan bahwa aspek tersebut penting, namun diberikan Poli Umum dan Spesialis Rumah Sakit Jiwa Menur surabaya dengan kinerja yang belum sesuai, sehingga konsentrasi dan menaruh perhatian penuh pada aspek pelayanan tersebut.

\section{Waktu tunggu periksa $\leq 60$ menit}

Berdasarkan Keputusan Menteri Kesehatan Nomor 129/ Menkes/ SK/ II/ 2008 tentang Standar Pelayanan Minimal Rumah Sakit, salah satu standar minimal rawat jalan adalah waktu tunggu periksa $\leq$ 60 menit. Pada aspek ini responden menilai bahwa waktu tunggu periksa $\leq 60$ menit pada pelayanan Poli Umum dan Spesialis Rumah Sakit Jiwa Menur Surabaya mempunyai kinerja yang tidak baik, hal ini dapat diketahui dari mean penilaian responden terhadap aspek ini lebih kecil $(2,44)$ dari mean performance timeliness $(2,84)$, sehingga aspek ini terdapat pada kuadran I Hal tersebut dikarenakan Poli Umum dan Spesialis Rumah Sakit Jiwa Menur mengikuti program BPJS sehingga melayani banyak pasien, selain itu keterbatasan jumlah tenaga medis seperti dokter dan perawat juga dapat menyebabkan penilaian pada aspek ini menjadi tidak baik. Jam buka pelayanan rawat jalan pukul 08.00 -
13.00 setiap hari kerja

Menurut Keputusan Menteri kesehatan Nomor 129/Menkes/SK/II/2008 tentang Standar Pelayanan Minimal Rumah Sakit, salah satu standar minimal rawat jalan jam buka pelayanan adalah pukul 08.00 - 13.00 setiap hari kerja, kecuali hari Jumat pukul $08.00-11.00$

Aspek ini terdapat pada kuadran IV menunjukkan responden menilai baik kinerja jenis pelayanan yang telah diberikan Poli Umum dan Spesialis Rumah Sakit Jiwa Menur Surabaya, namun responden tidak mengharapkan dan menilai tidak penting aspek tersebut.

Berdasarkan hasil penelitian dapat disimpulkan bahwa tingkat kepentingan responden terhadap pelayanan Poli Umum dan Spesialis Rumah Sakit Jiwa Menur Surabaya berdasarkan Dimensi ketepatan waktu (timeliness) adalah responden menilai sangat penting terhadap seluruh aspek pada dimensi ketepatan waktu (timeliness). Hal ini terbukti dengan penilaian masing-masing aspek oleh responden memiliki nilai mean yang mencapai 4, khususnya pada aspek waktu tunggu periksa $\leq$ 60 menit $(3,58)$. Nilai mean dari aspek tersebut berada di atas nilai mean ketepatan waktu (timeliness) $(3,33)$.

Penilaian Responden Terhadap kinerja Pelayanan Poli Umum dan Spesialis Rumah Sakit Jiwa Menur Surabaya Berdasarkan Dimensi Kualitas ketepatan waktu (timeliness) menunjukkaan bahwaresponden menilai aspek waktu tunggu periksa $\leq 60$ menit pada pelayanan Poli Umum dan Spesialis Rumah Sakit Jiwa Menur Surabaya mempunyai kinerja yang tidak baik, hal ini dapat diketahui dari mean penilaian responden terhadap aspek ini lebih kecil $(2,44)$ dari mean performance timeliness $(2,84)$. 
Hasil pemetaan pada dimensi kualitas ketepatan waktu (timeliness) menunjukkaan bahwa aspek prosedur administrasi (pendaftaran) $\leq 10$ menit dan waktu tunggu periksa $\leq 60$ menit. berada pada kuadran I. Hal ini berarti bahwa spek tersebut penting, namun diberikan Poli Umum dan Spesialis Rumah Sakit Jiwa Menur Surabaya dengan kinerja yang belum sesuai. Poli Umum dan Spesialis Rumah Sakit Jiwa Menur Surabaya harus konsentrasi dan menaruh perhatian penuh pada aspek pelayanan tersebut. Sedangkan untuk aspek jam buka pelayanan rawat jalan pukul $08.00-13.00$ setiap hari kerja terletak pada kuadran IV yang beratrti bahwa responden menilai baik kinerja jenis pelayanan yang telah diberikan Poli Umum dan Spesialis Rumah Sakit Jiwa Menur Surabaya, namun responden tidak mengharapkan dan menilai tidak penting aspek tersebut.

Berdasarkan ketiga aspek yang terdapat dalam dimensi ketepatan waktu (timeliness) aspek waktu tunggu periksa $\leq 60$ menit memiliki nilai mean gap yang paling besar adalah $(-1,14)$, dan dari keseluruhan aspek dalam dimensi ketepatan waktu (timeliness) responden masih belum puas terhadap kinerja yang diberikan oleh Poli Umum dan Spesialis Rumah Sakit Jiwa Menur Surabaya.

\section{SIMPULAN}

Berdasarkan hasil penelitian dapat disimpulkan bahwa responden tidak puas pada pelayanan yang ditinjau dari dimensi ketepatan waktu (timeliness) diberikan Poli Umum dan Spesialis Rumah Sakit Jiwa Menur Surabaya.
Berdasarkan hasil Importance Performance

Analysis terhadap dimensi ketepatan waktu (timeliness) saran yang diberikan adalah memperbaiki kedisiplinan perawat dan dokter yang bertugas di Poli Umum dan Spesialis Rumah Sakit Jiwa Menur Surabaya dengan cara membuat Standar Operasional Prosedur ketepatan waktu dokter, perawat, dan petugas administrasi dalam melayani, standar waktu tiap jenis pelayanan dan standar waktu tunggu pelayanan.

\section{DAFTAR PUSTAKA}

Aditama, T.Y. (2003). Manajemen Administrasi Rumah Sakit, Edisi Kedua . Jakarta: PenerbitUnversitas Indonesia (UI Press)

Anjaswarni, T. (2002). Analisis tingkat kepuasan klien terhadap perilaku caring perawat di Ruang rawat instalasi rawat inap RSUD Saiful Anwar Malang. Jakarta : FIKUl.

Azwar, A. (2008). Pengantar Administrasi Kesehatan. Edisi Kelima. Jakarta. Binarupa Aksara.

Brandt,. D.R. (2000). An "Outside-In" Approach to Determining Customer Driven Priorities for Improvement and Innovation. White Paper Series. Vol 2-2000

Evans, W. and Lindsay. (2007). Pengantar Six Sigma. Jakarta: Salemba Empat

Hock, C. and Sarstedt, M. (2010). Management of multi-purpose stadiums: Importance and performance measurement of service interfaces. International Journal of Services Technology and Management, 14(2), 188207

Lupiyoadi, R dan Hamdani, A., (2006), Manajemen Pemasaran Jasa, Salemba Empat, Jakarta.

Magal, S \& Levenburg, N. (2005). Using ImportancePerformance Analysis to Evaluat e-business Strategies Among Small Business. Preceeding of 38 th. Hawaii International Conference on System Science

Notoatmodjo, S. 2012. Promosi kesehatan dan Perilaku Kesehatan. Jakarta : Rineka cipta

Sihombing, U. (2002). Membangun Kepuasan Pelanggan melalui Pelayanan. Jakarta: Erlangga

Simamora, B. (2004). Panduan Riset Perilaku Konsumen. Jakarta: Gramedia Pustaka Utama

Tjiptono, F. (2004). Manajemen Jasa. Edisi Pertama. Yogyakarta: Penerbit Andi

Tjiptono, F dan Chandra. (2007). Strategi Pemasaran. Edisi Kedua. Yogyakarta: Penerbit Andi. 